\title{
Impact of digital media on emotional, social and moral development of children
}

Roman Globokar**
roman.globokar@teof.uni-lj.si

https://doi.org/10.31192/np.16.3.8

UDK/UDC: 316.774:004-053.5]:17

37.064.2:159.954

Izvorni znanstveni rad /Original scientific paper Primljeno/Received: 22. kolovoza 2018. / August 22, 2018 Prihvaćeno/Accepted: 5. kolovoza 2018. / November 5, 2018

Digital media is radically changing the way people communicate and influencing the thought processes and experiences of children and adults. New technologies pose a challenge to the educational process. The paper presents the results of the latest research on the impact of digital technology on the emotional, social, and moral development of children. School should respond to the challenges of the digital world by promoting self-respect among children, emotional development, community affiliation, creativity, and innovation. Furthermore, the key to the success of the educational process is the creative passion of the teacher.

Key words: Digital Age, Holistic Development of Children, Loneliness, Selfrespect, Community, Creativity.

\section{Introduction}

We live in the digital age and modern digital media have a significant impact on the educational process as well. The paper will first present the results of research on the impact of digital media on the emotional, social, and moral development of children, and then it will formulate some recommendations on how school should respond to the challenges of the digital age so that children and young people can develop as holistically as possible and prepare adequately for an independent and responsible life.

\footnotetext{
* Roman Globokar, PhD, Assist. Prof., Moral Theology, Faculty of Theology, University of Ljubljana; Address: Poljanska 4, SI-1000 Ljubljana, Slovenia.
} 


\section{Education in the Digital Environment}

Nothing has changed living in modern society as deeply as the massive use of mobile phones in everyday life. Mobile phones have pervaded each and every area of our lives: information, conducting business, communication, spirituality, entertainment, as well as education.

During our research on the impact of digital media on upbringing and education, we noticed that there has not been a lot of research done in this area yet. Some previous researches have come to the same conclusion. ${ }^{1}$ They also note that the methodology and research area have been developed and improved only in the recent years, which is the reason why there are still no relevant longitudinal studies. ${ }^{2}$

The fact is that one cannot remove oneself from this world; therefore, one must acknowledge the changes of human thought processes and experiences caused by new information technologies. Naturally, school should be aware of that as well. New technologies cannot shape a personality, which is a process that represents the primary role of school. The personality is always shaped in an interpersonal relationship. Digital media also cannot nurture critical thought and the ability to distinguish between real and virtual world. They can contribute even less to the emotional education of young people: emotions are formed within the cultural environment, with art and literature playing a very important role. When it comes to the area of physical and creative development, digital media once again do not have a decisive role.

Intuitively, we are all aware of the deep changes, brought about by digital technology. We can mostly see children and young people, as well as older people, being constantly in direct contact with their mobile phones. Through them they also connect with other people and create new networks of friends. Nowadays, it is possible to form a much larger network of friends than ever before in the history of mankind. Geographical distances do not play any significant role in that process anymore. Through the World Wide Web, it is possible to connect with people from close or far away and share with them our experiences, interests, thoughts, desires, etc. Social media today enable those who feel lonely within their local environment to feel connected with others on the other side of the world. All of the above, of course, affects how an individual behaves within the environment in which one lives physically. Therefore, some believe that social media also contribute to alienation, discrimination, and loneliness.

\footnotetext{
${ }^{1}$ Cfr. Christine GREENHOW, Julia SONNEVEND, Colin AGUR (ed.), Education and social media: toward a digital future, Cambridge, The MIT Press, 2016, 1.

${ }^{2}$ Rebecca NOWLAND, Elizabeth A. NECKA, John T. CACIOPPO, Loneliness and Social Internet Use: Pathways to Reconnection in a Digital World?, Perspectives On Psychological Science, 13 (2018) 1, 70-87, 71.
} 
Research in the United States has shown that, in recent years, the portion of families with access to mobile phones and tablets has increased sharply - from just over half (52\%) in 2011, through three quarters (75\%) in 2013, to almost the entire population of children (98\%) in 2017. ${ }^{3}$ In 2017, the Statistical Office of the Republic of Slovenia also offered similar findings: »Almost all households with children had a computer (97\%); half of them had a tablet computer, and 98\% of them had Internet access «. ${ }^{4}$ The Statistical Office of the Republic of Slovenia also records that $97 \%$ of young people between 16 and 24 regularly use computers, while $98 \%$ of them regularly use the Internet. The American study outlines how the use of mobile phones and tablets among children up to 8 years of age has increased: in 2011,38\% of the children used mobile devices, then in 2013 , the proportion rose to $72 \%$, while in $2017,84 \%$ of the children under the age of 8 used mobile devices. ${ }^{5}$ Many other studies have offered similar results. ${ }^{6}$ In 2010, an American study already stated that adolescents, on average, used modern technology for out-of-school needs 8 hours per day. ${ }^{7}$

In 2016, the American Academy of Pediatrics (AAP) issued the recommendations for parents and educators regarding the use of digital media among children up to the age of 8 years. Most recommendations were aimed at keeping children watching the screen as little as possible, and more so than anything else, at advising the adults to actively supervise the children's activity on a mobile device, to explain the use of the device, and, above all, the contents of the on-screen experience. ${ }^{8}$ While the previous recommendations had given a time limit of 2 hours per day, the recent ones focused more on the adult supervision during the use of digital media.

What is the role of school in all of this? Digital dualism which would lead to the exclusion of modern technology from school life is certainly not a solution. If that happened, pupils would experience an even greater divide between school and the rest of their living environment. It is definitely a great challenge

${ }^{3}$ Cfr. Victoria RIDEOUT, The Common Sense census: Media use by kids age zero to eight, San Francisco, CA, Common Sense Media, 2017, https://www.commonsensemedia.org/research/ the-common-sense-census-mediause-by-kids-age-zero-to-eight-2017 (28.03.2018), 3.

${ }^{4}$ STATISTIČNI URAD REPUBLIKE SLOVENIJE, Prvo četrtletje 2017: interneta doslej še ni nikoli uporabilo $18 \%$ oseb, starih 16- 74 let (06.10.2017), http://www.stat.si/StatWebPDF/ PrikaziPDF.aspx?id=6998\&lang=sl (31.07.2018), 1.

${ }^{5}$ Cfr. Rideout, op. cit., 24.

${ }^{6}$ Cfr. Jennifer L. MILLER et al., Looking beyond swiping and tapping: Review of design and methodologies for researching young children's use of digital technologies, Cyberpsychology, 11 (2017) 3, 31-51.

7 Cris ROWAN, Unplug - don't drug: A critical look at the influence of technology on child behavior with an alternative way of responding other than evaluation and drugging, Ethical Human Psychology and Psychiatry, 12 (2010) 1, 60-68.

8 »As with traditional, print-based literacy practices, parental engagement in digital literacy was crucial to the children's experiences and could provide a solid foundation for future learning in schools « [Jackie MARSH et al., Young Children's Initiation into Family Literacy Practices in the Digital Age, Journal of Early Childhood Research, 15 (2017) 1, 47-60, 55]. 
how to instruct young people in the responsible use of digital assets. How to use modern digital resources so that the young can develop intellectually, but also emotionally, socially, and ethically. It is therefore a challenge to how modern technology should help an individual to fully develop their potentials and the whole society to be more humane, and just, and to consider the possible negative ramifications of the progress for the natural environment.

\section{Results of Research on the Impact of Digital Media on the Development of Children}

\subsection{Impact on Emotional Development}

The use of new information devices deeply affects the development of cognitive and emotional processes in young people because it transforms the way of thinking. It transforms it from an analogue, structured, sequential, and referential one into a general, vague, global, and holistic one. It changes our experiences as well since digital media bring closer the distant things and move away the things that are close to us. Introducing us to the depiction of the world and not the world itself, they convey the presence without the real dimensions of time and space. Everything is simultaneous and momentary. ${ }^{9}$

Nowadays, one of the most significant changes is the pace of acquiring knowledge and information. Using the Internet, one can immediately get the answer to the posed question. The intermediate stage of excitement during the search for the answer is therefore disappearing, along with yearning and uncertainty. There is no longer an intermediate time between the desire and the gratification, which naturally changes one's experience. There is no more room for patience, for the process, for creating strategies, for facing frustrations and problems, etc.

Umberto Galimberti claims that there is a high level of malnutrition among young people in their emotional development. He believes that today's young people are overwhelmed with experiences in their early childhood, which they cannot process. They are skilled in fast responses, but they are not capable of critical distance and reflection.

»Currently, the emotional world of our children is crowded and agitated, and they are shifted by it without being aware of it, without being able to develop any reflection, which they have not learned to do, to calm down the excitement and replace the desire with practical solutions that can even be violent as long as they gratify the desire.$^{10}$

\footnotetext{
${ }^{9}$ Cfr. Umberto GALIMBERTI, La parola ai giovani: dialogo con la generazione del nichilismo attivo, Milano, Feltrinelli, 2018, 16-17.

${ }^{10}$ Umberto GALIMBERTI, Grozljivi gost: nihilizem in mladi, Ljubljana, Modrijan, 2010, 36.
} 
According to Galimberti, the excessive emotivity and insufficient reflection can only end in four ways: 1 ) the apathy of the emotional apparatus (going to clubs, taking drugs); 2) not being interested in anything (indifference); 3) violence; 4) creative genius (when the emotional charge is accompanied by strict self-discipline).

Digital media determines the development of today's children in many ways. Above all, this is apparent in the tendency to expect instant gratification of their needs and the instant wish-fulfilment. Similarly to Galimberti, Yamamoto and Ananou note that the way of technological functioning affects the emotional development:

»The rise of technology-facilitated conversation appears to be conditioning individuals to expect instant gratification either by initiating the virtual interaction or by responding to it«. ${ }^{11}$

Of course, digital technology itself does not force us to respond immediately and there is always the possibility for a delayed response and reflection. In fact, that is what really makes us human. Therefore, it is very advisable to think carefully about how we will react and to consider possible future consequences before sending a particular email. It is a new implementation of the ancient ethical virtues of prudence and temperance that need to be developed in the digital age. For that reason, it is necessary to start educating children from an early age to develop and cultivate their instincts, to understand that it is not possible to acquire everything with just one click and that there is an intermediate time between the desire and the gratification of the desire, to understand that it is not always possible to fulfil one's desires and that there are other people as well who also have their own needs and desires.

It is very important that our decisions are not just an instinctive response, but that we can control the momentary impulses that are often triggered by digital media. The great challenge is how to endure not responding immediately to the sound of a beep alerting us to a new message, either an email, a text message, or a new instant message on Messenger, Facebook, Skype, Viber, etc. Having studied the brain's activity, we know that complex thinking takes place in the neocortex, while during emotional excitement, the amygdala takes over the decisive role and limits the activity of the thinking brain. To establish a quality learning and thinking process, we need an environment that does not disturb us emotionally. If we are emotionally disturbed by various electronic messages, then we cannot actually think straight, instead we are dependent on the momentary impulses that are coming from the outside. In such a state, it is also difficult to respond appropriately to the messages we receive and it can

\footnotetext{
${ }^{11}$ Junko YAMAMOTO, Simeon ANANOU, Humanity in the Digital Age: Cognitive, Social, Emotional, and Ethical Implications, Contemporary Educational Technology, 6 (2015) 1, 1-18, 2 .
} 
easily happen that we later regret our quick and reckless reaction to a particular message. ${ }^{12}$

Because of digital media, the option of multitasking (handling multiple tasks simultaneously) has been expanded. Today, we can listen to music, watch $\mathrm{TV}$, read an e-book, write text messages, talk to someone live, etc. Multitasking is presented almost as a great virtue, skill, or ability. However, research suggests that students who send text messages during lectures or do other things on digital media are getting worse exam results. ${ }^{13}$ Our brains are not capable of doing intensively more than one thing at the same time.

For a healthy development of emotions, personal contact with other people is very important. Research has shown that the increased use of electronic media reduces the development of empathy among young people. ${ }^{14}$ There is a decline in the sense of empathy among the American students from 1979 to $2009 .{ }^{15}$ It is a fact, therefore, that the use of digital technology can adversely affect the emotional development of children since it reduces the time for direct contact with others and the ability to deal with the emotions of another person. ${ }^{16}$

For most people it is much easier to criticise specifically or send a negative message in the virtual world because one does not immediately get an emotional response from the other person.

»People tend to care about each other's feelings when another person is in the same room. The digital age sometime offers a blurred sense of reality. When one cannot see another's facial interaction in an online environment, she may make a rude remark, forgetting there is a real person at the receiving end «. ${ }^{17}$

There is another very important aspect when we assess the impact of digital technology on human development and on our perception and thinking. During face-to-face communication, body language plays a very important role since it conveys or rather signifies the content of the message. In virtual communication, this dimension is not present. Many electronic devices allow a quick reaction to the message without it being necessary to formulate a thought and use words. This way, we can click on the thumbs-up emoji, heart emoji, angry face emoji, or any of the numerous other pre-formulated responses.

\footnotetext{
${ }^{12}$ »When one is under the influence of text messages, instant messaging, social media, or emails that make him or her upset, it is possible that that the ability to think rationally is undermined. If the individual responds while she is upset, it is possible that she sends a digital message that she would later regret sending (Ibid., 9).

${ }^{13} \mathrm{Cfr}$. Mark L. CARRIER et al., Causes, effects, and practicalities of everyday multitasking, Developmental Review, 35 (March 2015), 64-78.

${ }^{14} \mathrm{Cfr}$. Jeffrey S. McQUILLEN, The influence of technology on the initiation of interpersonal relationships, Education, 123 (2003) 3, 616-623.

${ }^{15}$ Cfr. Sara H. KONRATH, Edward H. O'BRIEN, Courtney HSING, Changes in Dispositional Empathy in American College Students Over Time: A Meta-Analysis, Personality and social psychology review, 15 (2011) 2, 180-198.

${ }^{16}$ Cfr. Yamamoto and Ananou, op. cit., 6.

${ }^{17}$ Ibid., 5.
} 


\subsection{Impact on Social Development}

\subsubsection{Lack of the Meta-communication Level}

Modern digital media in a way facilitate the forming and maintaining of relationships. But if that does not lead to real relationships, then they do not actually help a person to evolve, instead they exhaust us. On the Internet, the relationships are less risky and less painful, and it is easier to withdraw. In real life, on the other hand, the development of genuine interpersonal relationships requires hard and demanding work, which in the end makes the individual fully human. On the Internet, the relationships can end with a single click.

People constantly communicate on at least two levels: the first is the level of the communication through words, language, messages, and the second is the level of »meta-communication«, which provides these linguistic messages with their con-text. In fact, the latter level decides on the very meaning of the message. As Patrick Carnes says:

»The messages sent at this level emphasize or tone down the messages given at the basic level. They are given along with the tone of voice, face expression, body movement, touch, and other forms of non-verbal communication «. ${ }^{18}$

Digital media disable the conveyance of meta-messages. That way, they go a step further from the phone that still enables us to hear the colour and the dynamics of the voice.

Social networks allow us to create a virtual self through which we can share with others what we want them to know about ourselves. Usually it is more difficult to resolve conflicts within the virtual world because there is a lack of body language, tone of voice, etc. in communication, which makes it much easier to get into a misunderstanding. In addition, written messages can be forwarded to others and are therefore open to abuse. A negative comment on Facebook leaves deeper consequences for an individual than face-to-face criticism in front of a group of people. ${ }^{19}$

\subsubsection{Link between loneliness and social media}

The social context in which children and young people grow up is nowadays marked by individualism. The desires and needs of an individual are the most important, and the function of the society is to provide the highest possible growth of individual potentials. Autonomy, freedom, and tolerance are the main values in our society. Nevertheless, the today's postmodern individual is still seeking validation from others. He/she strives for the thumbs-ups, for the response of others, and does not want to be alone.

\footnotetext{
${ }^{18}$ Patrick CARNES et al., V senci interneta, Ljubljana, Modrijan, 2010, 112.

${ }^{19}$ Cfr. Yamamoto and Ananou, op. cit., 5.
} 
Social networks are created so that individuals can connect and communicate with each other. Observations and research prove that today's youth, despite all the connections, feel very lonely and often do not see any prospects for the future. Studies show that the feeling of loneliness in society is generally greater than 20 years ago and the greatest among young people between 18 and 35 years. ${ }^{20}$ Are the Internet and new social networks to blame for that? Based on the research so far, two basic hypotheses can be deduced:

1) Hypothesis of Displacement: Social media displace direct interpersonal face-to-face relationships, therefore, causing the increase of the feeling of loneliness among young people. The use of certain forms of social media is associated with a higher level of loneliness. The increased use causes thoughts and feelings of isolation. However, the same research also shows that lonely people seek the comfort of social media more and use them as a substitute for direct interpersonal relationships.

2) Hypothesis of Stimulation: Social media stimulate and strengthen direct interpersonal face-to-face relationships. Certain studies indicate that new social face-to-face relationships are being forged with the help of social networks, and, above all, the already established relationships are strengthened. Working together with friends online leads to the direct personal relationships that are of better quality.

Researcher Rebecca Nowland and her colleagues note that the context is the key when it comes to the interpretation of the results. In some cases, the use of social media increases the feeling of loneliness, and in other cases it even reduces it.

"When social media is used as a way to make new friends, enhance existing relationships or maintain long distance ones it can reduce loneliness. But when social media is used in a way that replaces face-to-face communication it increases loneliness ${ }^{21}$

\footnotetext{
${ }^{20}$ Cfr. Nowland et al., Loneliness and Social Internet Use..., 70. In the interview for the German newspaper Die Zeit, the researcher Nowland recently stated this about the reasons: »Die Erwartungen an uns selbst sind enorm gestiegen. Das führt einerseits dazu, dass wir schneller das Gefühl haben, dass etwas mit uns nicht stimmt. Auf der anderen Seite sind wir so sehr damit beschäftigt, unser Leben zu optimieren, dass wir uns immer weniger Zeit für soziale Kontakte nehmen.« [Rebecca NOWLAND, Einsamkeit: »Ich nenne es das Bridget-Jones-Phänomen« (17.02.2018), https://www.zeit.de/campus/2018-02/einsamkeit-forschung-social-media-rebecca-nowland-interview (27.04.2018)].

${ }^{21}$ Rebecca HARRIS, Loneliness: A Rising Epidemic in Modern Life? (24.07.2015), http://www. expertwitnessjournal.co.uk/special-reports/656-loneliness-a-rising-epidemic-in-modern-life (25.06.2018). Also compare with the statement of the same person (although with a different surname) three years later: »When the Internet is used as a way station on the route to enhancing existing relationships and forging new social connections, it is a useful tool for reducing loneliness. But when social technologies are used to escape the social world and withdraw from the «social pain > of interaction, feelings of loneliness are increased." (Nowland et al., Loneliness and Social Internet Use..., 70).
} 
The problem arises when social media replace direct relationships. In any case, an overview of research clearly shows that young people want more friends and more in-depth direct relationships than they currently have, which is also the reason why the feeling of loneliness among them is so prevalent.

The research has showed that the concept of friendship among teenagers has changed, moving from the quality level to the level of quantity. One is more valuable if one has more friends on Facebook. ${ }^{22}$ However, we all know that despite 1000 friends on Facebook, one can still be lonely if one does not have any friends with whom one would be very close and whom one would trust completely. The research actually indicates that the more time people spend on Facebook, the more they feel lonely. Nevertheless, in this case as well, the more precise analysis shows that those who use Facebook to replace and avoid direct relationships feel lonelier than those who use Facebook to form new friendships and maintain direct contacts.

Another research has indicated that the prevalence of online violence among children between the ages of 8 and 12 is associated with their loneliness in real life. ${ }^{23}$

\subsubsection{Importance of direct relationships}

By all means, direct interrelationships are essential for the healthy development of an individual.

»Positive relationships with others are like essential vitamins or minerals for us, promoting our physical and mental health. People with good quality social connections are healthier and have increased life expectancy«. ${ }^{24}$

Unfortunately, it is noticeable that due to the use of mobile phones, strangers almost no longer establish a contact with each other, for example, on the bus, at the airport, also outside lecture halls at faculties, or classrooms in schools. Everyone communicates through their mobile phones, while the communication between the people in the immediate vicinity is sadly disappearing. However, it is the direct, face-to-face contact that carries an irreplaceable importance for forming an individual's personality.

\subsection{Impact on moral development}

The objective of moral development is an independent and responsible person who recognises the other as a person with the same rights and duties, who

\footnotetext{
${ }^{22}$ Cfr. Nowland, Einsamkeit...

${ }^{23}$ Cfr. Corrie L. SCHOFFSTALL, Robert COHEN, Cyber Aggression: The Relation between Online Offenders and Offline Social Competence, Social Development, 20 (2011) 3, 587-604; Yamamoto and Ananou, op. cit., 5.

${ }^{24}$ Harris, op. cit.
} 
is capable of reasonable decisions and is able to choose the good for himself/ herself, for society, and for the entire natural environment. A moral personality makes decisions in an autonomous, reasonable, and responsible way. Human behaviour is not the result of external impulses, but of internal contemplation. A moral personality is the master of their own actions who takes on the responsibility for the consequences of their decisions.

Moral development is internally connected with social and emotional development. The prerequisite for a moral decision is emotional maturity and social sensitivity. It is always a sensible decision that transcends bare impulses and involves other people as equals. At the same time, it emphasizes the irreplaceable role of a functioning subject. No one else can make a particular moral decision for oneself.

A child progressively develops their ability of moral thinking (Piaget, Kohlberg) and action. At first, the older ones take responsibility for deciding what is good for the child, and later on, he/she gradually assumes responsibility for his/her own actions. The child decides on the principle of what is useful and comfortable for him/her. During puberty, the price of acceptance among peers is to forswear certain desires for the benefit of the common good. Later, she/he acknowledges the importance of specific social norms and rules and gradually integrates them into their own values that guide them in life. ${ }^{25}$

The digital world strongly co-shapes both family and social life, and has therefore an impact also on the development of moral perception.

If one looks at the impact of digital technology on the social level of ethics, then one can conclude that modern technology has helped to improve the possibilities for the overall development of people. It has allowed knowledge to be universally accessible practically to all people on all the continents. It has also enabled intercultural exchange and cooperation in a particular project between people from all over the world.

However, this also makes it more difficult to protect intellectual property and easier to plagiarise. We are confronted with a very challenging issue of intellectual honesty as the facilitated way of access to data and of the creation of one's work is a great temptation for pupils, students, and adults around the world. The following observation of the researcher is interesting in this regard:

"While only a small portion of students admit giving into the temptation to copy others' work and submit it as their own, a large majority of students perceive cyber-plagiarism as a practice that is prevalent among their peers « ${ }^{26}$

Modern digital media also require the new ethical responsibility of users, and it is the school's task to teach pupils digital ethics as well, for example, how

\footnotetext{
${ }^{25}$ Cfr. David R. SHAFFER, Katherine KIPP, Developmental Psychology: Childhood and Adolescence, 9 ed., Belmont, Wadsworth Cengage Laarning, 2014, 513-525.

${ }^{26}$ Yamamoto and Ananou, op. cit., 7.
} 
to cite the texts, photos, or movies of other authors in a presentation, etc. In addition, various web applications can be helpful, for example, https://www. commonsense.org/education/ in English, or http://www.ethics-education.eu/ tools/index-hr.htm in Croatian.

Due to the abundance of data that is available online, the ability of critical thinking, which needs to be developed from an early age, is now even more important than in the past when it comes to ethical development.

»Critical thinking is thinking, which is based on the use of reason, i.e. it is guided in an appropriate manner by (good) reasons as opposed to e.g. uninformed desires and inclinations, prejudices, fears, awards and fear of punishment etc. It is reflective thinking, which deals with what to believe or what to do«. ${ }^{27}$

It is very important that we equip children with basic tools of critical thinking already in the early years: clarity, argumentation, justifiability, transparency of assumptions, durability, non-contradiction, validity, consistency, noncircularity, etc.

A distinctive challenge is also ethical pluralism that labels modern society. The global connection with different cultures and ethical views of the world allows the individual to come into contact with various ethical traditions. The exit route from a given situation is not necessarily moral relativism, instead it is possible to enrich our own tradition with the traditions of other cultures and to find common ethical foundations for the coexisting of the entire human family. The fact is that there are no universally accepted ethical values, and we are still in the process of creating global ethics.

There are, however, some general fundamental values that emerge from the concept of human rights, such as respect for the dignity of human life, freedom, equality, prohibition of any discrimination, tolerance, justice, etc., but they are interpreted differently in particular cultural contexts. For the healthy moral development of children, certain clarity and consistency of parents and educators regarding moral orientations is important. The modern research among children also shows this:

»The 4- to 9-year-olds in the sample favoured any form of discipline, even love withdrawal, over a permissive attitude on the parent's part (which they viewed as 'wrong' or 'very wrong'). Apparently young children see the need for adults to step in and restrain their inappropriate conduct, for they were disturbed by stories in which children were completely free to do their own thing «. ${ }^{28}$

\footnotetext{
${ }^{27}$ Bruno ĆURKO, Vojko STRAHOVNIK, Play as a way to developing critical thinking in ethics education: the example of Ethika project, in: Anikó NAGY, Pálfi SÂNDOR (ed.), Játékkal a világ körül [Play around the world], Debrecen, Debreceni Egyetemi Kiadó [Debrecen University Press], 2016, 5-16, 8.

${ }^{28}$ Shaffer and Kipp, op. cit., 526.
} 


\section{Recommendations for the educational process}

The objective of education is to promote a holistic development of an individual in order to become a good person, to understand as much as possible themselves and the world around them, to be creative, responsible, and compassionate. Technology can help with this development, but it can also hinder and limit it. Regarding the latter, it is not so important whether the use of technology is actually the cause of emotional and social problems or whether it only reveals the problematic dispositions that the individual carries within themselves. ${ }^{29}$ The fact is that digital technology is an important part of the environment in which we live and therefore has a significant impact on the development of children and young people.

To conclude, this article would like to make some recommendations for the field of education and upbringing in the digital age.

\subsection{Promotion of self-respect among children}

In a world that bombards us with the advertising images of a happy and perfect life, it is essential that children and young people learn self-respect. It is about the children's ability to develop within themselves the feeling and conviction that they are worthy of love and that they are capable of living. The school process should be geared towards children becoming more and more familiar with themselves, discovering their potentials, and appreciating themselves. This is not a false and superficial positive self-image, but a genuine discovery of oneself and recognition that one is worthy of one's life having value. The paper emphasizes once again that by promoting self-respect, one does not mean creating an idealized image like the one used on Instagram or on Facebook, but a genuine introspection and self-respect. Today, there is a great danger that children and young people, as well as adults, confuse their identity with the desired image of themselves, which they create in the virtual world. As the paper tried to show, the feedback from the virtual world cannot give us the validation that we need as people to keep developing into a personality. For this one needs a concrete relationship, face-to-face contact, emotional affection, a caring touch, satisfaction with a collaborative creation, etc. To a great extent, school can also provide children with that. Psychologists find that the ability to learn is to a large extent related to the sense of self-respect that pupils developed within themselves: the motivation for learning grows with the development of the sense of self-respect. ${ }^{30}$

\footnotetext{
${ }^{29}$ Cfr. Yamamoto and Ananou, op. cit., 2.

${ }^{30}$ Silvo ŠINKOVEC, Vzgojni načrt v šoli: spodbujanje celostnega razvoja osebnostni učencev, Ljubljana, Jutro, 2017.
} 
Psychologist Galimberti points out that because of the need to be accepted and loved young people lose their way. He also adds:

"Young people need to be educated to be what they are, exactly what they are. That is mental strength. But to be able to be what they are, they must accept their shadow with their arms open wide. That is what we reject when it comes to ourselves «. ${ }^{31}$

It is important to learn to live with errors as well, including imperfection and vulnerability. The life experiences of loss, failure, and regression are not only negative and unnecessary, but are also important messages that guide us during our personal growth. ${ }^{32}$

\subsection{Emotional Education}

School plays a very important role in the emotional education of children and young people. It is vital to learn how to recognize one's emotions and talk about them. To quote Silvo Šinkovec's words:

"The same way we learn languages, arithmetic, and computer science, we must also learn to live and deal with anger, fear, sadness, jealousy, shame, feelings of guilt, pride, love, joy, hope, etc. Emotions provide much needed information, and if we overlook them, we are at risk of making wrong decisions and treating ourselves and others badly. Emotional literacy is humus for respectful relationships $\ll^{33}$

Today's generations are supposed to have more emotional problems than the past generations.

»That is because today young people are more alone and depressed, angrier and more rebellious, more nervous and impulsive, more aggressive and, consequently, less prepared for life, because they do not have critical emotional tools that would induce self-confidence, self-control, and empathy; without these attributes they can speak, but cannot listen, cannot resolve disputes or participate ${ }^{34}$

Pupils should learn how to live with their emotions and how to cultivate them in a healthy way.

Developing empathy also plays an important role in all of this. As already mentioned, research shows that young people are less and less empathic. It is important that they can identify with somebody else, that they can put themselves into somebody else's shoes, that they can understand the other, their differences, as well as their resemblances.

\footnotetext{
${ }^{31}$ Galimberti, Grozljivi gost..., 46.

${ }^{32} \mathrm{Cfr}$. Edgar MORIN, Insegnare a vivere: manifesto per cambiare l'educazione, Milano, Rafaello Cortina Editore, 2015, 17-18.

${ }_{33}$ Šinkovec, op. cit., 192-193.

${ }^{34}$ Galimberti, Grozljivi gost..., 41.
} 


\subsection{Community Affiliation}

Humans are social beings. Modern neurological research suggests that the human activity is determined by the longing for affiliation, validation, and cooperation more than by egoism and rivalry. The German professor of medicine and psychotherapist Joachim Bauer therefore draws the following conclusion:

»A child can develop an individual, autonomous self only if he/she has constant, personal relationships through which the child is perceived in his/her particularity and his/her individuality is reflected. / ... / We cannot substitute the child's personal relationships with anything «. ${ }^{35}$

One of the school's purposes is to create a space where genuine interpersonal relationships can be formed. In the educational principles of one of the Catholic schools in Slovenia, it is written:

»Our educational guidelines stem from the belief that one can fully develop one's personality only within the community in which one feels accepted. Educational activities are primarily carried out within class communities and educational groups. The community allows the individual to develop, discover, and identify oneself and to assume responsibility for its construction. Through various activities, we encourage the pupil to participate with others and to accept and support them. Therefore, we are preparing him/her for teamwork and active co-creation of the society. To succeed in that, it is vital that the community of teachers acts as a role model $\ll{ }^{36}$

\subsection{Creativity}

In the digital world that is changing rapidly, creativity and innovation will be increasingly important. It is known that large computer corporations, when hiring, are mostly looking for creative people who are open-minded and think outside the box. In particular, artists, musicians, and humanists are in demand. Therefore, school should further promote art and creativity and not so much directly applicable knowledge, such as computer science, since that is changing very quickly. What we need is new ideas in the process of finding answers to the fundamental challenges in the life of an individual and society. During this process, it is important that teachers are as creative as possible in their lectures, since they are primarily educating simply by being a role model. Which brings us to the final part of this article: the teacher's passion.

\footnotetext{
${ }^{35}$ Joachim BAUER, Prinzip Menschlichkeit: Warum wir von Natur aus kooperieren, Hamburg, Hoffmann und Campe, 2006, 212.

${ }^{36}$ ZAVOD SV. STANISLAVA, Vzgojni načrt Škofijske klasične gimnazije, Ljubljana, Zavod sv. Stanislava, 2018, 14.
} 


\subsection{Teacher's Eros}

The French philosopher Edgar Morin is convinced that we need a new pedagogical revolution. The starting point for this is »creative passion«. In spite of all the information provided by the Internet, there is a lack of something essential: the passion of the teacher who passes on knowledge. Morin wrote:

»Despite sending all the messages through videos, Skype, and other channels, the Internet lacks the physical, corporeal, mental, active, reactive, and retroactive presence of the teacher, not as an assistant, but as a conductor of the orchestra who allows thinking, criticizing, and organizing Internet knowledge.$^{37}$

For the success of the pedagogical revolution, the eros of the conductor of the orchestra, that is, the passion of the teacher, is of crucial importance. The conductor of the orchestra draws attention to various traps, errors, inconsistencies, and limitations of their own findings. The conductor of the orchestra encourages listening to others, upgrading, striving for excellence, exceeding the average. The conductor of the orchestra is also aware of the vulnerabilities and weaknesses and can cope with uncertain and critical moments.

\section{Conclusion}

During the educational process, the paper believes that it is necessary, even in the digital age, to emphasize those abilities that promote a harmonic and holistic development of children. Perhaps even more than in the past, nowadays, at school, it is necessary to promote and develop emotional, social, and moral competences. As some of the fundamental answers to the challenges of the digital age regarding the educational process, the paper have underlined the efforts for promoting self-respect among pupils, emotional education, community creation, and creativity.

At the end, the paper expresses the desire that modern teachers will be able to extract the best from each pupil and at the same time unite individuals into a harmonious community, thus successfully preparing young people for all the unknown challenges in the digital future.

\footnotetext{
${ }^{37}$ Morin, op. cit., 104.
} 


\section{Roman Globokar*}

Utjecaj digitalnih medija na emocionalni, društveni i moralni razvoj djece

Sažetak

Digitalni mediji radikalno mijenjaju način na koji ljudi komuniciraju, te utječu na misaone procese i iskustva djece i odraslih. Nove su tehnologije izazov obrazovnom procesu. Ovaj rad donosi rezultate najnovijih istraživanja utjecaja digitalne tehnologije na emocionalni, društveni i moralni razvoj djece. Škola bi trebala odgovoriti na izazove digitalnog svijeta promicanjem samopoštovanja kod djece, emocionalnog razvoja, pripadnosti zajednici, kreativnosti i inovativnosti. Nadalje, ključ uspjeha obrazovnog procesa je kreativna strast učitelja. Ključne riječi: digitalno doba, holistički razvoj djece, usamljenost, samopoštovanje, zajednica, kreativnost.

(na hrv. prev. Ivan Nekić)

\footnotetext{
* Doc. dr. sc. Roman Globokar, Teološki fakultet, Sveučilište u Ljubljani; Poljanska 4, SI-1000 Ljubljana; E-mail: roman.globokar@teof.uni-lj.si.
} 